\title{
EDITORIAL
}

\section{(IN)SUFFICIENT LEGAL BASIS FOR THE PROPOSAL FOR REFORM OF REGULATION 883/2004 PRESENTED BY THE EUROPEAN COMMISSION ON 13.12.2016}

\section{CRISTINA SÁNCHEZ-RODAS NAVARRO}

Director of the International Journal of Social Protection

Article 48 of the Treaty on the Functioning of the European Union (TFEU) confers the Council the task of establishing a system enabling migrant workers to avoid any obstacles which may arise for them from the national rules laid down in the field of social security. In order to overcome these obstacles, the Regulations for the Coordination of Social Security systems were promulgated, which were initially applied only to workers, civil servants and self-employed persons.

Over the years, the personal scope has been extended and nowadays Regulation $883 / 2004$ is applicable not only to nationals of a Member State who are economically active, but also to non-active persons.

However, since coordination of social security systems has never been an end in itself but an instrument to ensure the free movement of workers, it must be underlined that Regulation 883/2004 itself states that in order to adopt the measures in the field of social security for persons other than employed persons, the Treaty does not provide for any powers of action other than those referred to in Article 308, now 352 TFEU. That is why, for the enactment of Regulation 883/2004, a dual basis was used: Article 48 of the TFEU and Article 308 (now 352).

Therefore, since the proposal for the reform of Regulation 883/2004 of 13.12.2016 (which concerns non-active persons) presented by the Commission is based on Article 48 TFEU, it must be concluded that this article alone is not a sufficient legal basis to undertake a restrictive reform of the rights of persons who are not active, to which Article 48 TFEU is not applicable since their right to freedom of movement derives from Article 21 TFEU. 